\title{
IDENTIFYING ENABLING MANAGEMENT PRACTICES FOR EMPLOYEE ENGAGEMENT
}

\author{
Marius Joubert: Department of Industrial Psychology and People Management, Faculty of \\ Management, University of Johannesburg \\ Gert Roodt: Department of Industrial Psychology and People Management, Faculty of \\ Management, University of Johannesburg
}

Orientation: A currently emerging viewpoint is that today's management practices no longer add value to organisations. The focus of this article is to conduct a systematic review of the scholarly literature on management practices that could be related to employee engagement.

Research purpose: This study searched for evidence in support of the notion of a management value chain, and enabling management practices within each value chain component that could relate to employee engagement.

Motivation for the study: An alternative management value chain model could contribute towards a better understanding of which management practices may potentially impact employee engagement.

Research design, approach, and method: This is a non-empirical (theoretical) study, based on a systematic, in-depth literature review to identify the key management components and enabling practices within this proposed management value chain. Scholarly research databases were sourced for relevant peer reviewed research conducted since 1990, not excluding important contributions prior to 1990 . The literature was systematically searched, selected, studied, and contextualized within this study.

Main findings: Support was found for the notion of a management value chain, for enabling management practices within each proposed management value chain component, and it was also established these management practices indeed have an impact on employee engagement.

Practical/managerial implications: The possibility that management work can be presented as a generic management value chain allows managers to approach engaging management practices more systematically.

Contribution/value-add: This study highlights the importance of some management practices that have never been seen as part of management work.

Key words: engaging management practices; empowering management practices; management value chain; theoretical study; employee engagement; organisational performance; model building.

\section{INTRODUCTION}

In an interview with Harvard Business Review, Gary Hamel (Allio, 2009, p. 10) noted: 'Management is the single largest constraint on business performance.' Current management models and practices need to be reviewed, because managers no longer seem to be able to add significant value to their organisations. An important study on business school curriculums by Weinstein and Barrett (2007) suggested that managers should learn how to add value in their organisations.

In 2007, the Hay Group conducted a study that showed that middle managers in the United Kingdom cost the economy approximately £220 billion per annum (Paton, 2007). According to a Towers Perrin Global Workforce study (2007), overall employee engagement in organisations across the world was $21 \%$, whilst disengaged employees totalled $38 \%$. The Towers study further showed that managers are playing a significant role in the above statistics. 
The present study focuses on the concept of creating a management value chain for management to ensure consistent application of enabling management practices in order to contribute to the improvement of employee engagement and, ultimately, organisational performance. The present study used Porter's (1985) model for competitive advantage, and draws a parallel between the organisational value chain and the notion of a management value chain.

The main aim of the study, therefore, was to develop a management value chain model by conducting a systematic literature review. Firstly, the potential components of a proposed management value chain had to be identified. Secondly, the enabling management practices that are related to employee engagement had to be identified. Thirdly, the relationship between employee engagement and organisational performance had to be identified.

Evidence from a preliminary literature review could not find any evidence of the existence of such a management value chain. Hence, no specific engaging management practices could be linked to such management value chain components. However, sufficient evidence was found that employee engagement does impact organizational performance (Bassi \& McMurrer, 2007; Caborn, 2003; Matthews, 2008; Morgan \& Anthony, 2008; Wigham, 2003).

The study contributes to the body of knowledge in terms of Management 2.0 (Hamel, 2009) and provides an alternative model for management. The premise of the findings in this study allude to the possibility that managers should be able to focus on very specific management practices in their management roles that could impact employee engagement. Employee engagement for the purpose of this study is defined as: "an effective state that reflects employees' personal satisfaction and a sense of inspiration and affirmation they get from work and being part of the organization" (a Towers Perrin definition, as cited by Schaufeli and Bakker, 2010, p.12). If managers are able to apply certain management practices consistently, they will be able to more effectively engage people, which should improve organisational performance.

In the remainder of this article, the authors provide first a brief overview of the engagement literature, followed by a description of the research design and an explanation of the associated research approach and method. A detailed outline of the research findings is provided and, subsequently, management implications of the study are discussed.

\section{An overview of the literature}

Management as an organisational variable has been studied extensively over decades to determine what impact it has on organisations, its people, processes, and systems. Research literature relating to the individual components of the proposed management value chain model was found, but no research reference to a management value chain was made specifically. There was no indication of an existing management value chain model that would help managers to understand which management practices are important to improve employee engagement and how this relates to company performance.

\section{The notion of a management value chain}

The current available literature on management does not make reference to management as a so-called value chain. Scholars studying the specific phenomenon of management refer to a management process (Hales, 2001) or management work (Butcher \& Clarke, 2003; Lau \& Payett, 1980; O'Gorman, Bourke \& Murray, 2005; Pearson \& Chatterjee, 2003), or to management activities and roles (Haikonen, Savolainen \& Jarvinen, 2004; Konrad, Kashlak, Yoshioka, Waryszak \& Toren, 2001; Schermerhorn, 2004; Van der Velde, Jansen \& Vinkenburg, 1999). Some researchers have studied management within the context of a management model (Birkinshaw \& Goddard, 2009). There are, however, other researchers that studied the application of management process, activities, and roles within specific industry disciplines like travel management (Douglas \& Lubbe, 2005), maintenance management (Aoudia, Belmokhtar, \& Zwingelstein, 
2008), supply chain management (Caddy \& Helou, 2007), hospitality management (De Holan \& Mintzberg, 2004), financial management (De Young, 1998), management of sport organisations (Papadimitriou \& Taylor, 2000), and management of customer relationships (Peppard, 2000).

Michael Porter's (1985) work on competitive advantage seems to be the only study illustrating the importance of a value chain. Although this value chain is related to organisational systems, it does provide some understanding that a value chain can add value to improving the effectiveness of management within organisations (Pfeffer (2005), indicated that achieving a sustainable competitive advantage requires a fundamental change in the way we think about the workforce and the manager-employee relationship. The more effective managers become in applying their management work and in managing people more effectively, the more they will be able to increase the organisation's competitive advantage. Glaser (2006) found that managers' ability to negotiate adds value to the efficiency of the organisational value chain. Porter's (1985) Value Chain model could therefore be used to illustrate the potential competitive advantage that managers could add to a management value chain.

Preliminary evidence suggests that the notion of a generic management value chain or management process possibly exists. In the Veldsman and Roodt (2002) benchmark study, the majority of organisations implicitly indicated, on a practical level, that they have been dealing with critical management issues that can be conceptualised as a management value chain.

\section{The critical management practices relating to employee engagement}

Several researchers have studied management effectiveness in different contexts. The following researchers identified the need for investigating the impact of management effectiveness in organisational contexts: Aoudia et al., 2008; Hamel, 2009; Hamlin, 2002; Hamlin \& Cooper, 2004; Hamlin \& Sawyer, 2007; Hamlin \& Serventi, 2008; Hasan \& Hunter, 1996; and Page, Wilson \& Meyer, 1999.

Hamlin and Serventi (2008) studied 25 effective- and 25 ineffective management and leadership behaviours in a government institution in the United Kingdom. They found that managers who exhibit effective management behaviours (Hamlin \& Serventi, 2008) such as quickly and proactively deal with issues, gathering all the relevant facts and data and making informed decisions, regularly praising employees on achievements, showing appreciation, supportively listening to the work concerns of employees, and planning and preparing well in advance for meetings are more likely to be perceived as effective managers. These behaviours were identified by employees of Wolverhampton City Council Social Care as effective management behaviour that had the biggest impact on people.

Page et al. (1999) completed a study to develop a three-domain, two-dimension model of managerial effectiveness. Their findings suggested that a communicative and participative style of management and leadership, where people are valued and relationships are built, are important factors in effective management practices.

The literature pertaining to effective management practices also indicates that there is a school of thought where management practices are linked to specific processes such as total quality management (Da Silva, Tadashi \& Kikuo, 2005; Flynn et al., 2007) and Six Sigma (Lloréns-Montes \& Molina, 2006). According to Patterson, West, Lawthom, and Nickell (1997), there is a relationship between effective people management and financial results. Conversely, the literature also indicates that some variables contribute to low levels of employee engagement. According to Kerfoot (2007), employee engagement starts with the Leader.

Existing literature does not provide us with a systematic understanding of the possible link between specific management work, activities, and management practices and the direct impact it might have on 
employee engagement. It seems that no study exists where engaging management practices are systematically linked to components of a management value chain specifically.

\section{Employee engagement and organisational performance}

Existing literature pertaining to employee engagement and/or commitment highlights its contribution to organisation results (Bassi \& McMurrer, 2007; Caborn, 2003; Matthews, 2008; Morgan \& Anthony, 2008; Wigham, 2003). Davidson (2003) and Wiley, Brooks, and Hause (2000) published articles on how organisational culture and climate impact on organisational performance. Huselid, Jackson, and Schuler (1997) and Patterson et al. (1997) studied the relationship between human resource management practices and the impact thereof on the financial performance of an organisation.

Research conducted in other areas such as supply chain management (Tan, Kannen, Handfield \& Ghosh, 1999), customer relationship management (Peppard, 2000), and quality management (Flynn, Schroeder \& Sakakibara, 2007) established the impact on organisational performance. Some researchers have even studied the impact of financial benefit/participation schemes for employees and its impact on financial performance of organisations (McNabb \& Whitfield, 1998).

Recent studies in the field of human capital metrics have provided empirical data and models to measure the economic value of human capital in organisations (Flamholtz, 2005). Intellectual capital and knowledge management as variables for organisational performance have also been studied (Marr, 2004; Marr, Schiuma \& Neely, 2004; Seetharaman, Teng Low \& Saravanan., 2004).

However, it seems that very few studies focus on management effectiveness as a contributor to the financial performance of organisations. Costeo (2003) identified top management practices and their impact on organisation results, such as profitability, market returns, and organisation size. The effectiveness of these practices could be described as critical management practices for employee engagement.

The current literature available on management and leadership is extensive. Bassi and McMurrer (2007), Kular, Gatenby, Rees, Soane, and Truss (2008) and Simpson (2008) provide some understanding from a transformational leadership perspective, but the evidence that systematically explains the relationship between management practices and employee engagement is insufficient. Bakker, Demerouti, Hakanen, and Xanthopoulou (2007) and Bakker and Demerouti (2007) refer to the concept of job resources and job demands. Job demands are one set of conditions for employee wellbeing in an employee's job that create strain and stressors, whilst job resources reduce the impact of job demands and contribute to achieving work objectives, and provide personal growth, learning, and development.

This preliminary literature review highlights a possible gap in the current research regarding representing management as a value chain and indicating that managers are, in fact, instrumental in the process of increasing the competitive advantage of organisations. Due to the nature of the constructs under investigation, it is clear that significant amounts of research have been done on issues pertaining to management effectiveness. It is, however, clear that there is little research evidence that an integrated management model exists that establishes the effect of critical management practices that management should perform to improve overall employee engagement and, consequently, organisational performance.

\section{RESEARCH DESIGN}

\section{Research approach}

This study could be categorised as a theoretical (non-empirical) study. More specifically, the author conducted a systematic literature review with the objective to develop and propose a conceptual management value chain model based on the Mouton (2001) approach. These types of literature reviews 
are inductive in nature. According to Mouton (2001), this is an important criterion for the final quality of a literature review. Towards the end of the study, the findings were represented in a conceptual model (Figure 3) that portrays the components of the proposed management value chain.

\section{Research method Location of the data}

Management as a construct has been studied since the 1900's. It was therefore important to focus the study in terms of sources utilized as well as the period under investigation to ensure that the latest research and thinking can be obtained without excluding earlier ground-breaking research that could still be relevant to this study. EBSCO Host, a multi-disciplinary and business search portal, was utilised to identify the relevant peer reviewed articles. From this portal, articles were primarily drawn from databases such as Emerald - a management, science, engineering, and technology database. These databases were sufficient to identify the most recent and relevant peer reviewed articles for this study. It was important to ensure that there is sufficient depth in the number and quality of research articles selected to thoroughly study the constructs.

Eighty percent of the research referred to in this study was completed between 1990 and 2009. Very little 'ever-green' studies, completed prior to 1990, which still provided good models for interpretation, such as Porter's model for competitive advantage, were used.

\section{Data gathering methods}

Data was gathered using the databases provided by the University of Johannesburg's library, as mentioned above. The data was searched using the following key words: management value chain, critical management practices, enabling management practices, critical management enablers, empowering management practices, management effectiveness, employee management processes, and employee management methodology. Reference lists of articles were reviewed for additional publications that may not have been properly indexed and not found via electronic searches. Internet searches of professional organisations were also conducted to provide background data. Three selection criteria were used for selecting articles for this study: they had to be written in English or a translated version had to be available, the articles had to examine any of the constructs under investigation, and the article had to address at least one of the research questions asked in this study, either directly or indirectly.

The author discovered that, in some searched documents, direct empirical links were reported between the constructs relevant to the context of this study. However, other indirect evidence was also reported that provided sufficient evidence that the management components as proposed in the value chain do exist.

\section{Research procedure}

A comprehensive and well integrated literature review is essential to any study (Mouton, 2001). It provides a good understanding of issues and debates in the area of research, current theoretical thinking and definitions, as well as previous studies and their results.

An integrated literature review is important due to the number of researchers who have studied management effectiveness over the last few years in search of an understanding of how certain variables impact on management effectiveness. The purpose of this research was to consolidate the research published within a specific time frame, evaluate all the relevant constructs, and, ultimately, propose a model for understanding the relationship between the constructs.

This non-empirical (theoretical) research study was conducted in two phases. Phase 1 entailed the literature review on all the relevant constructs and Phase 2 included the development of an integrated, conceptual model. 
Figure 1 below illustrates what research procedure was followed in line with the requirements of replication or repeatability.

Figure 1: Research procedure

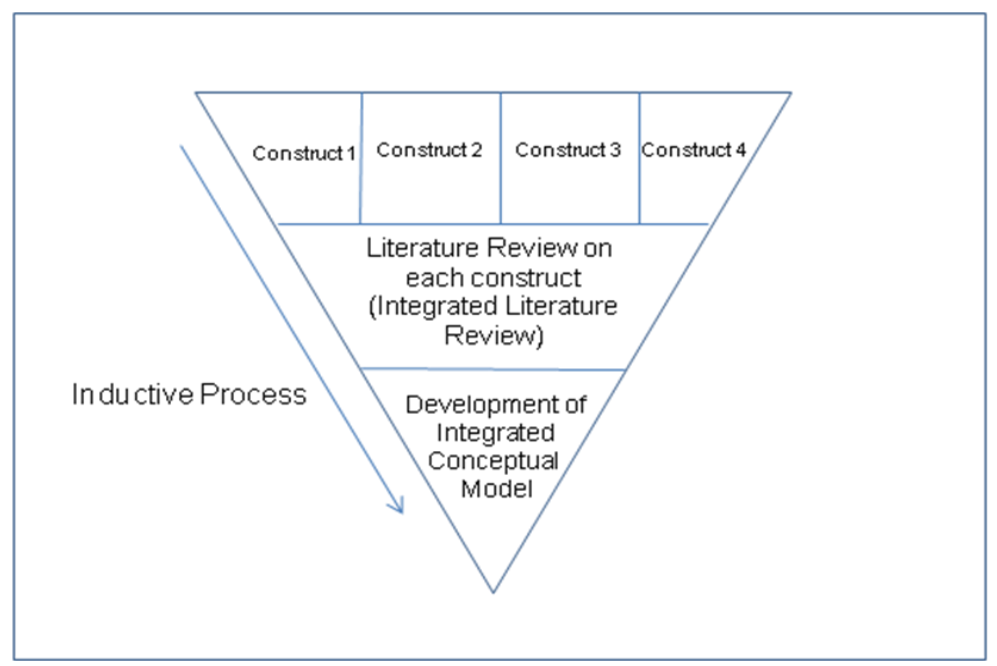

(Adapted from Mouton, 2001)

\section{Data analysis}

The relevant studies were selected after each search, using the sources and criteria indicated above. The constructs identified in the study were presented in table format in order to compare the findings of the different studies. The purpose was to create an overview of present literature on the constructs under investigation, and to identify the appropriate researched links to the components of the proposed management value chain.

Visual representation of the data provided sufficient understanding of the relationship between the research literature and the relevant component in the proposed management value chain.

\section{FINDINGS}

The findings of the study are reported in terms of the following research questions:

- What are the components within a proposed management value chain?

- What are the management practices that result in employee engagement in the proposed management value chain components?

- Does employee engagement relate to organisational performance?

\section{Components of a generic management value chain}

From the obtained textual data (research literature), it became evident that there is sufficient evidence to support the existence of a generic management value chain model by using the following key components mentioned in the research literature.

Environmental scanning. According to the literature, various studies (Costa, 1995; Jennings \& Lumpkin, 1992; Yasai-Ardekani \& Nystrom, 1996) have been conducted that indicate that a potential relationship exists between management and the construct environmental scanning. The literature suggested that 
management in general has not been sufficiently involved in this process, and this could have a negative effect on the level of management effectiveness.

Creating vision. Collins (1995), Hodgkinson (2002), and Morden (1997) provided some insight into the relevance of creating a vision within the management role. Hodgkinson's (2002) study found that managers feel that the level of their influence in their own areas was restricted by senior managers. They also provided case studies that indicated how visioning processes contributed to creating an understanding of how the process of visioning links with other important organisational elements such as training as well as product and service quality. It was suggested that the process of creating a vision is also part of middle-level and frontline-level managers' responsibility.

High-performance organisation design. The author found that this component included a range of other dimensions that managers need to take into consideration. This component historically fell within the ambit of the human resource practitioner. However, some elements in this component will remain the responsibility of the functional or line manager. Researchers (Curado, 2006; Dervitsiotis, 2008) indicated that organisations must develop the internal capability and competency to deal with complexities posed by the external environment. Managers have the primary responsibility of developing and maintaining environmental scanning processes and, consequently, also have the ability to ensure that the organisation is designed appropriately to deal with these complexities. A clear relationship exists between this proposed management value chain component and the management role.

Selecting and managing core competent talent. In this study, it was found that talent management as a concept is perceived very differently by various organisations. Mead and Rogers (2001) identified human capital as one of the key business processes, and suggested that, without this management capability, human resources will impact the business in a negative way instead of positively influencing the work environment. Hughes and Rog (2008) indicated that managers have a key responsibility to select, develop, and retain talent. Through these processes, they could potentially impact employee levels of engagement and commitment. Therefore, the link between selecting and managing talent and the role of managers within organisations was confirmed.

Stakeholder satisfaction. The research relating to stakeholder satisfaction highlighted the importance of not only external but also internal stakeholders (Dervitsiotis, 2003; Yarrow et al., 2004; Zakhem, 2007). Kanji (2008) contextualised stakeholder satisfaction within business excellence and business performance models. The important role of managers to manage the stakeholder satisfaction processes within their own functional areas was highlighted. In addition, customer-centric behaviour by employees as well as customer-centric processes will remain the responsibility of line managers.

Business performance. This particular component was also identified as a multi-dimensional variable due to the various elements that could contribute to an organisation's business performance. Tan et al. (1999) found that managers must ensure that their implementation strategies and standards are aligned with the areas of finance, operations, marketing, product development, and sales. This indicated that managers should be accountable for business results. Lloréns-Montes (2006) concluded that managers must ensure that leadership, learning, systems, knowledge, skill, and effort are part of this process in order to ensure consistent business performance.

Change navigation. Diefenbach (2007) reported a definite relationship between managers and the role they play in change initiatives. They have a responsibility to facilitate change initiatives in an engaging manner. In this component, it is evident, according to Applebaum et al. (2007), that managers require transformational management capability in terms of communication, leading people, facilitating change, and managing stress levels. These variables were linked to the level of responsibility and accountability of management and leadership teams within the context of change initiatives. The relationship between these two constructs was confirmed.

With reference to the first research question, it is evident that the findings could be represented in a generic management value chain as indicated below. 
Figure 2 - Proposed Generic Management Value Chain (Adapted from Veldsman \& Roodt, 2002)

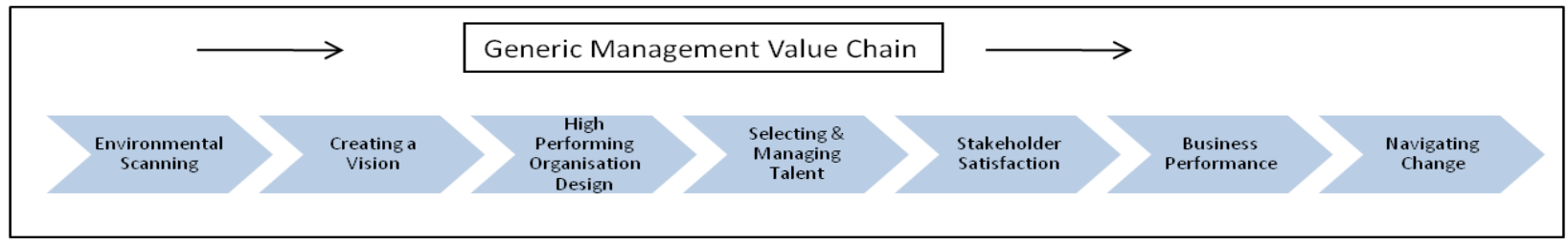

In respect of the first research question, it is important to note that the model implies that a relationship exists between the various value chain components, and that it is the responsibility of managers to perform specific tasks within each of these components. This model expands the Porter (1985) model, more specifically within the context of a management value chain. It is argued that, if management teams can execute their responsibilities within the context of this value chain, the process will positively influence bottom line results.

\section{Engaging management practices in a generic management value chain}

The purpose of the second research question was to establish which management practices within each of the value chain components result in employee engagement.

A large number of studies were found that provided evidence that researchers studied these particular management practices and, in many instances, the authors found that indirect relationships existed between the actual management practice and the proposed management value chain component. In this section, the link between management practices and employee engagement is specifically addressed. The practices identified in each management value chain component have been categorised in Table 1 below in terms of a direct, indirect, or suggested relationship between management practices and the construct of employee engagement.

The researcher found that various management practices have a direct relationship with employee engagement, while others seem to have an indirect or suggested relationship with employee engagement. Some of these practices have been identified as part of the managers' role, but the success thereof will largely depend on how effectively managers perform these practices in their organisations, which will determine what impact it will have on the level of employee engagement. Practices such as creating an engaging story of the future has not been part of the traditional role of managers, but could have a significant impact on the ability of managers to facilitate change from the onset by engaging people in a vision-creation process. This will facilitate the operational implementation of that vision.

It is important to note that all the practices indicated in column 1 have some influence on employees from the perspective of employees being informed, participating in processes, being involved in processes or practices, developing new skills and knowledge, and being empowered by having more authority or autonomy. These practices will facilitate more engagement of employees and even managers in the development and implementation organisational processes.

Management practices that have an indirect relationship with employee engagement have been identified in this study, and are listed in Table 1 below. These management practices could not be directly linked to employee engagement, but there is definitely an indirect relationship through one or more of the direct relationship management practices listed in Table 1. It is important to note that most of these management practices, such as business processes, organisation structure, systems and technology, and efficiency and effectiveness will not have a direct impact on the level of employee engagement but, as a 
result of the process applied in these elements, could have an indirect impact on employee engagement. If managers unilaterally improve business processes, it might not impact employee engagement, but if managers improve business processes through and with employees, the process will have an engaging effect.

Management practices that seem to have suggested relationships with employee engagement are listed in column 3 in Table 1. Little research could be found that links these practices directly or indirectly. However, when reviewing these practices individually, some of them could potentially be moved to any of the first two columns. Cross-functional integration is the concept of removing silo thinking and silo operations in organisations. No research has been conducted to determine the relationship thereof with employee engagement, but cross-functional integration implies improved coordination and communication between managers, with their functions resulting in more effective business processes. Business processes have been identified as having an indirect relationship with employee engagement.

Table 1: Comparison between direct, indirect, and suggested relationships between management practices and engagement

\begin{tabular}{|c|c|c|}
\hline Column 1 & Column 2 & Column 3 \\
\hline $\begin{array}{l}\text { Management Practices with a } \\
\text { direct relationship with }\end{array}$ & $\begin{array}{l}\text { Management practices with an } \\
\text { indirect relationship with } \\
\text { employee engagement }\end{array}$ & $\begin{array}{l}\text { Management practices with a } \\
\text { suggested relationship with } \\
\text { employee engagement }\end{array}$ \\
\hline Being informed of environment & Business processes & Develop an ES system \\
\hline Visualise possible future & Organisation structure & $\begin{array}{l}\text { Analysis, interpretation, and } \\
\text { integration }\end{array}$ \\
\hline Leadership support & Setting performance standards & Implementation of plans \\
\hline Roles and responsibilities & Systems and technology & Evaluate success \\
\hline Develop talent & Efficiency and effectiveness & $\begin{array}{l}\text { Assess } \\
\text { effectiveness }\end{array}$ \\
\hline Resource provisioning & Select talent & Analysis and strategic review \\
\hline Participation and delegation & $\begin{array}{l}\text { Set business objectives and } \\
\text { standards }\end{array}$ & Coordination \\
\hline Performance feedback & Job design and structure & Strategic review \\
\hline Rewards & $\begin{array}{l}\text { Create } \\
\text { behaviour }\end{array}$ & $\begin{array}{l}\text { Determine } \\
\text { expectations }\end{array}$ \\
\hline $\begin{array}{lll}\begin{array}{l}\text { Employee } \\
\text { involvement }\end{array} & \text { satisfaction and } \\
\end{array}$ & Process and product quality & Employee knowledge and skills \\
\hline $\begin{array}{l}\text { Effective communication and } \\
\text { market intelligence }\end{array}$ & Continuous improvement & Measure and manage retention \\
\hline Managing performance & Customer orientation & $\begin{array}{l}\text { Formulate and implement } \\
\text { competitive strategy }\end{array}$ \\
\hline Strategic decision making & Pro-active business orientation & Manage and control information \\
\hline Participative orientation & $\begin{array}{l}\text { Plan for and create short term } \\
\text { wins }\end{array}$ & Cross-functional integration \\
\hline Establish burning platform & & Form guiding coalitions \\
\hline $\begin{array}{l}\text { Create a vision and an } \\
\text { story of the future }\end{array}$ & & $\begin{array}{l}\text { Consolidate improvements, } \\
\text { produce more change }\end{array}$ \\
\hline
\end{tabular}




\section{Joubert}

G. Roodt

IDENTIFYING ENABLING MANAGEMENT PRACTICES FOR

EMPLOYEE ENGAGEMENT

\begin{tabular}{|l|l|l|}
\hline $\begin{array}{l}\text { Communicate and deploy the } \\
\text { vision }\end{array}$ & Institutionalise new approaches \\
\hline $\begin{array}{l}\text { Operationalise the story and } \\
\text { translate to operational plans }\end{array}$ & & \\
\hline Empower others to act & & \\
\hline
\end{tabular}

In the following sections, the specific engaging management practices are explicated in more detail.

Environmental scanning was identified as the first potential management component within the proposed management value chain. The practices identified in the research (Albright, 2004; Costa, 1995) indicated that managers should be involved in the development and/or utilisation of a well defined environmental scanning system. The literature (Decker, Wagner \& Scholtz, 2005) suggested that managers should be involved with the analysis, interpretation, and integration of data collected in this system and could therefore impact the implementation of action plans relevant to managers' functional areas. It was also suggested (Jennings \& Lumpkin; 1992; Subramanian, Fernandes \& Harper, 1993; Slaughter, 1999) that managers should be involved in the evaluation of the success of the implementation plans by re-scanning the environment to identify any potential variances. Finally, managers should be involved in assessing organisational effectiveness in its response to environmental factors that could potentially influence the organisation (Decker et al., 2005; Yasai-Ardekani \& Nystrom, 1996).

Creating a vision refers to the capability of creating, deploying, and operationalising the vision within a strategic process. This component implies that managers should be involved practically with this process and its associated practices (Costa, 1995; Kraut \& Pedigo; 1989; Levin; 2000). In many circumstances, the vision creation process is limited to the senior executive team of the organisation, with only operational input from managers. Recent literature suggests that organisations can benefit from designing innovative ways to allow the entire organisation to participate in the vision creation process. The practices indicated in Figure 5.3 indicate that visualisation of possible futures (Den Hartog, Van Muijen \& Koopman, 1997; Kenny, 1994; Levin, 2000), creating engaging storyboards, and communicating or deploying the vision through the minds of every employee (Baldoni, 2006; Levin, 2000; Morgan, 2007), including the process of finding ways to operationalise the story in the organisation (Bauer et al., 2005; Kanji, 2008), might have a significant impact on the organisation.

High-performance organisation design has been defined as a multi-dimensional component in the proposed management value chain. Involvement in the development and deployment of an organisational vision implies input into this component. Strategic review and clarity are the starting points of this process (Da Silva et al., 2005; Garg \& Singh, 2005), followed by a range of management practices that will contribute to the development of a high-performance organisation. It includes continuous leadership support (Beer, 2001; Curado, 2006; Dervitsiotis, 2008), which is an important requirement for the successful evaluation and implementation of new systems. The improvement of business processes (Dervitsiotis, 2008; Lillrank, Lindberg \& Lindberg, 2001), through and with employees, continuous evaluation and alignment of organisational structure (Cummings, 1965; Curado, 2006; Goold \& Campbell, 2002), clarification of roles and responsibilities (Kane-Urrabazo, 2006), the setting of business performance standards (Genaidy, Salem, Karwowski, Paez \& Tuncel, 2007; Marton, 2003), the establishment required systems and technology (Garg \& Singh, 2005; Sohal et al., 2001), the improvement of coordination and integration in and between functions (Curado, 2006; Garg \& Singh, 2005), as well as the improvement of efficiency and effectiveness of the organisation (Glick, Huber, Miller, Doty \& Sutcliffe, 1990; Goold \& Campbell, 2002) seem to be practices that will be future requirements for managers in organisations.

Talent management was identified as an important management component in the proposed management value chain, and has become a necessary management capability in organisations. Historically, the concept of talent management was within the scope of responsibilities of the human resources practitioners, with line managers were required to fulfil very specific practices within this area. 
The practices in this component include the review or alignment of organisational strategy in order to ensure that the talent management process will support the strategy (Veldsman, undated). Selecting talent (Wing, 2005), developing talent (Bahner \& Stroh, 2004; Huselid et al., 1997), setting objectives and performance standards (Baldoni, 2006; O'Conner \& DeMartino, 2006), ensuring that employees have sufficient resources to perform their jobs (Wing, 2005), facilitating a more participative environment with appropriate levels of delegation (Daft, 2004; Loch et al. 2007), and continuous performance feedback with subsequent rewards (Beechler, Woodward, 2009; Salaman \& Asch, 2002) are all practices that line managers need to perform to manage the talent in their organisational units. Strategic review, job design, and structure practices could be responsibilities that require more involvement from Human Resources; however, Human Resources will be responsible for providing the framework that will enable managers to perform these practices.

Stakeholder management was identified as the fifth component of the proposed management value chain. This component includes both the management of external and internal stakeholders, which could potentially have an impact on the organisation and its results. Managers will be required to determine all stakeholders' values and expectations (Cooper et al., 2001; Hamel, 2009; Long et al., 2008; Reidenbach \& Mcclung, 1999). Through effective communication, processes, and systems, the organisation should be managed to satisfy all stakeholders' expectations. Most of the practices, however, suggest that managers - depending on their functional role - will primarily focus on internal stakeholders, as the results of their satisfaction will impact external stakeholders. Practices such as creating customer-orientated behaviour (Tan et al., 1999; Verma \& Kajendra, 2004), employee satisfaction and involvement, employee knowledge and skills (Long et al., 2008), and measuring and managing employee and customer retention allude to internal stakeholder satisfaction (Kaplan \& Norton, 1992; Nohria \& Berkley, 1994). Pricing as a management practice refers primarily to external stakeholders (Reidenbach \& McClung, 1999; Verma \& Kajendra, 2006). Stakeholder value and expectations, effective communication, and market intelligence as practices include both internal and external stakeholders.

Business performance was identified as the sixth component of the proposed management value chain, and was traditionally seen as a management responsibility of ensuring that the business achieves its objectives and performs against set performance standards (Den Hartog et al., 2004). Some of the management practices identified within this component address a range of practices that managers are not performing optimally. These management practices are: continuous improvement (Bauer et al. 2005; Haikonen et al., 2004; Lee \& Choi, 2006), strategic decision-making (Andreou \& Bontis, 2007; Brown; 2005), participative orientation (Chien, 2004; Genaidy et al., 2007), business orientation, and crossfunctional integration (Griggs, 2003; Kraut \& Pedigo, 1989). Managers across the senior and mid-tier levels are also required to formulate and implement competitive strategies (Andreou \& Bontis, 2007; Boeker, 1997) in their organisational units, which must be aligned to the organisational strategy. All the other practices are elements that managers should be able to perform in order to contribute to business performance.

Navigating change is identified as a transformational management component in the proposed management value chain. Kotter (2007) provided a framework for this component and this author found substantiating evidence that these practices are required to successfully manage change in organisations. The practices identified in this component start with the ability to establish a burning platform in the organisation (Kotter, 2007; Kilgallon \& Lampe, 2007). Unless there is a reason to change, very few people will, in fact, co-operate with change. In order for managers to drive change, they need to create coalitions that will support the cause for change (Baldoni, 2006; Beer, 2001; Lu \& Botha, 2006). Vision, communication, and empowerment (Kotter, 2007; Page et al. 1999) are key requirements for driving change through an organisation. Planning and implementation of plans (Cunningham \& Hyman, 1995; Kaplan \& Norton, 1992) with the involvement and participation of employees will contribute to engaging employees in this process. Managers need this capability to navigate their organisations through constant change 
Figure 3: Proposed Generic Management Value Chain

\begin{tabular}{|c|c|c|c|c|c|c|c|}
\hline & \multirow[b]{2}{*}{$>\quad \begin{array}{c}\text { Environmental } \\
\text { Scanning }\end{array}$} & \multirow{2}{*}{$\longrightarrow$} & \multicolumn{3}{|c|}{ Generic Management Value Chain } & \multicolumn{2}{|l|}{$\longrightarrow$} \\
\hline & & & $\begin{array}{l}\text { High } \\
\text { performanc } \\
\text { org design }\end{array}$ & $\begin{array}{c}\text { Select core } \\
\text { competent } \\
\text { Talent }\end{array}$ & $\begin{array}{l}\text { Stakeholder } \\
\text { Satisfaction }\end{array}$ & $\begin{array}{l}\text { Business } \\
\text { Performance }\end{array}$ & $\begin{array}{l}\text { Change } \\
\text { Navigation }\end{array}$ \\
\hline \multirow[t]{2}{*}{ 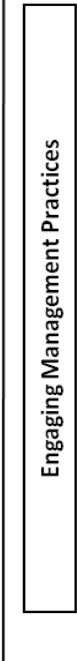 } & $\begin{array}{l}\text { Management } \\
\text { Practices } \\
\text { 1. Develop an ES } \\
\text { system (s) } \\
\text { 2. Analysis, } \\
\text { Interpretation and } \\
\text { Integration (S) } \\
\text { 3. Implementation } \\
\text { (S) } \\
\text { 4. Evaluate Success } \\
\text { Is) } \\
\text { 5. Re-Scan } \\
\text { 6. Assess } \\
\text { organisational } \\
\text { performance (S) }\end{array}$ & $\begin{array}{l}\text { Management } \\
\text { Practices } \\
\text { 1. Bieing informed } \\
\text { of environment (D) } \\
\text { 2. Visualise possible } \\
\text { Futures }[\text { I) } \\
\text { 3. Create the story } \\
\text { of the best future } \\
\text { (D) } \\
\text { 4. Deploying the } \\
\text { vision (D) } \\
\text { 5. Operationalise } \\
\text { the story (D) }\end{array}$ & $\begin{array}{l}\text { Management } \\
\text { Practices } \\
\text { 1. Analysis and } \\
\text { strategic view (S) } \\
\text { 2. Leadership } \\
\text { support (D) } \\
\text { 3. Business } \\
\text { processes (II) } \\
\text { 4. Organisation } \\
\text { structure (I) } \\
\text { 5. Roles and } \\
\text { Responsibilities (D) } \\
\text { 6. Performance } \\
\text { standards (I) } \\
\text { 7. Systems and } \\
\text { Technology (I) } \\
\text { 8. Coordination and } \\
\text { integration (S) } \\
\text { 9. E. Eficiencyand } \\
\text { effectiveness (I) }\end{array}$ & $\begin{array}{l}\text { Management } \\
\text { Practices } \\
\text { 1. Strategic choice } \\
\text { IS) } \\
\text { 2. Select talent (I) } \\
\text { 3. Develop talent } \\
\text { (D) } \\
\text { 4. Set objective \& } \\
\text { Standards (I) } \\
\text { 5. Resource } \\
\text { provision (D) } \\
\text { 6. Participation \& } \\
\text { Delegation (D) } \\
\text { 7. Performance } \\
\text { feedback (D) } \\
\text { 8. Rewards (D) } \\
\text { 9. Job design and } \\
\text { structure (II) }\end{array}$ & 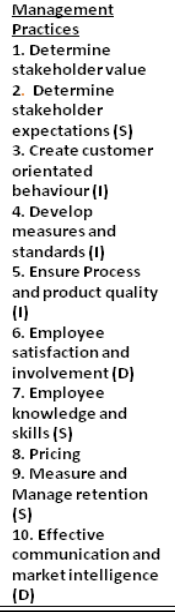 & $\begin{array}{l}\text { Management } \\
\text { Practices } \\
\text { 1. Formulate and } \\
\text { implement } \\
\text { competitive } \\
\text { strategy (s) } \\
\text { 2. Manage } \\
\text { performance (D) } \\
\text { 3. Continuous } \\
\text { improvement (1) } \\
\text { 4. Management } \\
\text { informationand } \\
\text { control (D) } \\
\text { 5. Strategic Decision } \\
\text { making (D) } \\
\text { 6. Customer } \\
\text { orientation (1) } \\
\text { 7. Pro-active } \\
\text { business } \\
\text { orientation (I) } \\
\text { 8. Participatory } \\
\text { orientation (D) } \\
\text { 9. Crossfunctional } \\
\text { integration/collabo } \\
\text { ration (S) }\end{array}$ & $\begin{array}{l}\text { Management } \\
\text { Practices } \\
\text { 1. Establish burning } \\
\text { plattorm/sense of } \\
\text { urgenchy (D) } \\
\text { 2. Forming guiding } \\
\text { coalitions (S) } \\
\text { 3. Create avision } \\
\text { 4. Communicate } \\
\text { the vision (d) } \\
\text { 5. Translate to } \\
\text { operational plans } \\
\text { 6. Empowerothers } \\
\text { to Act (D) } \\
\text { 7. Plan for and } \\
\text { create short-term } \\
\text { wins (I) } \\
\text { 8. Consolidate } \\
\text { improvements and } \\
\text { produce more } \\
\text { change (S) } \\
\text { 9. Institutionalise } \\
\text { new approaches (S) }\end{array}$ \\
\hline & \multicolumn{7}{|c|}{ As a result of engaging management practices, improved Organisational performance } \\
\hline
\end{tabular}

The relationship between employee engagement and organisational performance

With regard to the third research question, there was sufficient evidence in the literature that supported the existence of a relationship between employee engagement and organisational performance (Bassi \& McMurrer, 2007; Caborn, 2003; Matthews, 2008; Morgan \& Anthony, 2008; Wigham, 2003). Significant empirical research has already been done to validate and test the reliability of employee engagement as a construct that impacts business performance.

For the purpose of this study, it was important to identify a variable that managers will influence as a result of their management input. The variable selected was employee engagement. The study established that managers could have an impact on employee engagement through most of these management practices, directly or indirectly, resulting in improved organisational performance.

It therefore implies that managers are required to improve their level of management effectiveness by performing these practices consistently and effectively. By engaging employees' creative capability, developing them, involving them, and allowing them to participate in traditionally management practices and by providing them with constant information and feedback, managers will be able to increase the level of employee engagement.

As a result of the findings in each research question, the author could then populate the Generic Management Value Chain Model, as indicated in Figure 3 below. The Generic Management Value Chain includes specific components, its associated management practices, as well as the potential relationship they have with employee engagement. 


\section{DISCUSSION}

The focus of this article was to conduct a systematic review of the literature on management practices that could be related to employee engagement. More specifically, the aim of the study was to search for evidence in possible support of the notion of a management value chain and those enabling management practices within each value chain component that could possibly relate to employee engagement.

Research literature on the topic indicated that sufficient evidence exists in support of the notion of a generic management value chain. However, very few research articles were found that specifically studied this process. Most of the literature studied the constructs indirectly, but provided sufficient evidence that such a link does, in fact, exist. No other previous study systematically investigated the link between engaging management practices in a management value chain and employee engagement.

\section{Summary of key findings}

The first research objective of the study was to represent management as a generic value chain, and all the relevant research literature was studied to find substantiating evidence that such a management value chain could, in fact, exist. Research literature relevant to each management component was studied to verify their existence. The existing research literature indicated that the proposed management value chain components could be conceptualised as a generic management value chain (Barber, 2008; Porter, 1985). The first research question was hereby addressed.

The second research objective was to identify enabling management practices for each proposed management value chain component and to establish each one's relationship with employee engagement. Several engaging management practices were identified within each of the management value chain components (refer to Figure 3). Laschinger, Finegan, and Shamain (2002) integrated the Kanter Theory of organisational empowerment and the Conger-Kanungo's model of leader empowerment. Chien (2004) also alluded to the positive impact of delegation and participation on employees.

As indicated in Table 1, it was established that management practices have either direct, indirect, or suggested relationships with employee engagement. The second research question was hereby addressed.

The third, and last, research objective was to establish the link between employee engagement and organisational performance. This link has already been empirically tested (Bassi \& McMurrer, 2007; Caborn, 2003; Matthews, 2008; Morgan \& Anthony, 2008; Wigham, 2003), but it is nevertheless important to note that a link has been established between management effectiveness and employee engagement, and therefore also to business performance. The third research question was hereby addressed.

\section{Conclusions and managerial implications}

The most important conclusions emanating from this study were:

- Managers are currently not adding the full potential value.

- No reference was made in previous research literature to a model that reflected the management process as a value chain.

- No reference was made in previous research literature to a model that identified enabling management practices and contextualising it in a generic management value chain model.

- Insufficient evidence exists that systematically links all the engaging management practices to employee engagement.

- Although the link between employee engagement and business performance has already been established, very little research is available that directly links all the management practices' effectiveness to business performance. 
Should organisations decide to apply the generic management value chain model, there could be managerial implications on various levels:

- The way in which managerial effectiveness is formulated may by re-conceptualised in terms of employee engagement levels. Stated differently, this means that effective managers are those who have more engaged employees.

- The model could have a significant impact on the actual role of managers. The question is whether they will be able to do this practically if the number of management practices is considered.

- The proposed value chain model could also have a major impact on the process of management training and development. If managers are enabled with the necessary skills and knowledge required by their organisations, it could have a very clear and direct impact on the levels of employee engagement and also on potential staff turnover and talent retention. Unless the way in which managers engage with their organisations and their employees changes, it will be difficult to change the current value-add of managers.

- The authors became increasingly aware of the necessity for research to determine which management practices are required in organisations of the future. Given the fact that there is already an indication of a New Economic World Order (DeSilva, 2010), organisations will require managers to do things differently in order to become and remain competitive on a global scale. The proposed management value chain may contribute in this respect.

\section{Possible limitations of the study}

The current research (Hales, 2006; Hamlin \& Serventi, 2008; Luthans et al., 1988; Mintzberg, 1975) on management practices was conducted with present and past views in mind (Hales, 2006; Hamlin \& Serventi, 2008; Luthans et al., 1988; Mintzberg, 1975). It was also done based on employees' views and organisational challenges at the time. Organisational challenges are becoming more complex, which perhaps necessitates new research on management and leadership practices (regardless of whether it is transactional or transformational), based on future requirements.

Although this study suggests the existence of a generic management value chain, it still requires empirical validation. Further empirical research is required in each proposed management value chain component to validate the relevant management practices in each component. It would also add value to add statistical weightings and significance to each component, which will ultimately inform organisations regarding which management practices are non-negotiable in the process of improving employee engagement.

Given the current research design and methodology applied in this study, it may be possible that other relevant research literature was excluded. This may have an impact on the results of this study.

The study was performed on research that was conducted primarily since 1990. The ever-green research included studies from Porter (1985), Taylor (1911), and others. One of the main limitations of this study was that the authors did not consider future organisational requirements. These requirements could have a profound effect on required management practices of future organisations (Wailand, 2002).

\section{Suggestions for future research}

Based on the above conclusions and recommendations, the authors suggest that the following research could add value to the process of defining how the proposed management value chain model could impact individual managers as well as the organisations they represent. Additional research is necessary in this regard.

Empirical research is required to test the validity of the proposed management value chain model. 


\section{Joubert \\ G. Roodt}

Further empirical research is required into the management value chain components and how they individually impact employee engagement. Research is required to determine to what extent these management practices are being applied consistently by managers in organisations and, if these practices are not applied, what the reasons therefore might be. Future empirical research is required to determine if all these management practices are relevant to managers on different organisational levels. There may be different typologies for different management levels.

Further research is required to define Management 2.0 in order to determine how management practices should be adapted and improved to address the needs of organisations in the new world economic order. It will be important to evaluate how management practices differ in developed and developing countries. Is there a relationship between the level of competitiveness and the actual management capability? It would also be important to determine how the generic management value chain model could contribute to the continuous improvement of organisations in developed as well as developing countries as a result of improved management capability.

\section{CONCLUSION}

This study set out to determine if evidence exists that supports the notion of a management value chain, and also what the potential value chain components and associated enabling management practices within the proposed value chain would be. In addition, the study also set out to determine which of these management practices might potentially impact employee engagement and organisational performance. A preliminary review of the literature did not make any reference to a management value chain or to engaging management practices within such a value chain. A theoretical study research design was adopted as research approach and method for this study, within which a systematic literature review was conducted. The findings of the study provide support for the notion of a management value chain. Furthermore, the range of enabling management practices within each management value chain was identified, as well as the potential impact it may have on employee engagement. Finally, the link between employee engagement and business performance was confirmed. Hereby, the overall objective of the study was achieved.

This study provides an alternative model for management, and may improve the value that managers add to their organisations. Although empirical research is required to validate the model in its entirety, it does provide a different view that will add practical value to the quality of managers' input and the impact they have on employee engagement.

\section{REFERENCES}

Albright, K.S. (2004). Environmental Scanning: Radar for Success. Information Management Journal, 38(3), 38-45.

Allio, R.J. (2009). A conversation with Gary Hamel: it's time to reinvent management. Strategy and Leadership, 36(2), 5-10.

Andreou, A.N., \& Bontis, N. (2007). A model for resource allocation using operational knowledge assets. The Learning Organization, 14(4), 345-374.

Aoudia, M., Belmokhtar, O., \& Zwingelstein, G. (2008). Economic impact of maintenance management ineffectiveness of an oil and gas company. Journal of quality in Maintenance Engineering, 14(3), 237-261. 
Applebaum, S.H., Lefrancois, F., Tonna, R., \& Shapiro, B.T. (2007). Mergers 101 (Part one): training managers for communications and leadership challenges. Industrial and Commercial Training, 39(3), 128-138.

Bahner, R.R., \& Stroh, L.K. (2004). The transformation management model: A total evaluation route to business change success. Problems and Perspectives in Management, (4), 180-191.

Bakker, A.B., Demerouti, E., Hakanen, J.J., \& Xanthopoulou, D. (2007). Job Resources Boost Work Engagement, Particularly When Job Demands are High. Journal of Educational Psychology, 99(2), 274-284.

Bakker, A.B., \& Demerouti, E. (2007). The job demands-resources model: State of the art. Journal of Managerial Psychology, 22(3), 309-328.

Baldoni, J. (2006). Steady as you go: Achieving a balanced vision. Harvard Management Update, 11(8), 3-4.

Barber, E. (2008). How to measure the "value" in value chains. International Journal of Physical Distribution \& Logistics Management, 38(9), 685-698.

Bauer, J., Falshaw, R., \& Oakland, J.S. (2005). Implementing business excellence. Total Quality Management \& Business Excellence, 16(4), 543-553.

Bassi, L., \& McMurrer, D. (2007). Maximising your return on people. Harvard Business Review, 85(3), $115-123$.

Beechler, S., \& Woodward, I.C. (2009). The global "war for talent." Journal of International Management, 15(3), 273-285.

Beer, M. (2001). How to develop an organization capable of sustained high performance: Embrace the drive for results-capability development paradox. Organizational Dynamics, 29(4), 233-247.

Birkinshaw, J., \& Goddard, J. (2009). What Is Your Management Model? MIT Sloan Management Review, 50(2), 81-90.

Boeker, W. (1997). Strategic change: The influence of managerial characteristics and organizational growth. Academy of Management Journal, 40(1), 152-170.

Brown, P. (2005). The evolving role of strategic management development. The Journal of Management Development, 24(3), 209-222.

Butcher, D., \& Clarke, M. (2003). Redefining managerial work: smart politics. Management Decision, 41(5), 477-487.

Caborn, A. (2003). Could staff knowledge shape strategy? Director, 56(10), 32.

Caddy, I.N., \& Helou, M.M. (2007). Supply chains and their management: Application of general systems theory. Journal of Retailing and Consumer Services, 14(5), 319-327.

Chien, M.S. (2004). A study to improve organizational performance: A view from SHRM. Journal of American Academy of Business, 4(1), 289-300. 
Collins, D. (1995). The People investment process at Solihull Council - A Case Study. Management Development Review. 8(5), 15-17.

Cooper, S., Crowther, D., Davies, M., \& Davies, E. (2001). Shareholder or stakeholder value: The development of indicators for the control and measurement of performance. London: The Chartered Institute of Management Accountants.

Costa, J. (1995). An empirically-based review of the concept of environmental scanning. International Journal of Contemporary Hospitality Management, 7(7), 4-9.

Costeo, T. (2003). The financial impact of top management groups in Australian banking organisations. Unpublished doctoral Dissertation, Melbourne: University of Melbourne.

Cummings, L.L. (1965). Organisational climates for creativity. Academy of Management Journal, 8(3), 220-227.

Cunningham, I., \& Hyman, J. (1995). Transforming HRM vision into reality: The role of line managers and supervisors in implementing change. Employee Relations, 17(8), 5-20.

Curado, C. (2006). Organisational learning and organisational design. The Learning Organization, 13(1), 25-48.

Daft, R.L. (2004). Theory Z: Opening the corporate door for participative management. The Academy of Management Executive, 18(4), 117-121.

Da Silva, J.G., Tadashi, O., \& Kikuo, N. (2005). Looking through and beyond the TQM horizon - lessons learned from world-class companies. The TQM Magazine, 17(1), 67-84.

Davidson, G.M. (2003). The relationship between organisational culture and financial performance in a South African investment bank. Unpublished doctoral thesis, Pretoria: University of South Africa.

Decker, R., Wagner, R., \& Scholz, W.W. (2005). An internet-based approach to environmental scanning in marketing planning. Market Intelligence \& Planning. 23(2), 189-199.

De Holan, P.M. \& Mintzberg, H. (2004). Management as life's essence: 30 years of The Nature of Managerial Work. Strategic Organization, 2(2), 205-212.

De Young, R. (1998). Management Quality and X-Inefficiency in National banks. Journal of Financial Services Research, 13(1), 5-22.

Den Hartog, D.N., Boselie, P., \& Paauwe, J. (2004). Performance management: A model and research agenda. Applied Psychology: An International Review, 53(4), 556-569.

Den Hartog, D.N., Van Muijen, J.J., \& Koopman, P.L. (1997). Transactional versus transformational leadership: An analysis of the MLQ. Journal of Occupational and Organizational Psychology, 70(1), 19-34.

Dervitsiotis, K.N. (2008). Guiding human organisations to climb the spiral stages of performance improvements. Total Quality Management, 19(7-8), 709-718. 
Dervitsiotis, K.N. (2003). Beyond stakeholder satisfaction: aiming for a new frontier of sustainable stakeholder trust. Total Quality Management, 14(5), 511-524.

DeSilva, D. (2010). Managing \& competing in the new world economic order: Marketing at the core. Conference Proceedings of the $27^{\text {th }}$ Pan Pacific Business Conference, Bali, Indonesia.

Diefenbach, T. (2007). The managerialistic ideology of organisational change management. Journal of Organizational Change Management, 20(1), 126-144.

Douglas, A., \& Lubbe, B.A. (2005). Identifying value conflicts between stakeholders in corporate travel management by applying the soft value management model: A survey in South Africa, Tourism Management, 27(6), 1130-1140.

Flamholtz, E. (2005). Conceptualizing and measuring the economic value of human capital of the third kind - corporate culture. Journal of Human Resource Costing \& Accounting, 9(2), 78-93.

Flynn, B.B., Schroeder, R.G., \& Sakakibara, S. (2007). The impact of quality management practices on performance and competitive advantage. Decision Sciences Journal, 26(5), 659-691.

Garg, R.K., \& Singh, T.P. (2005). Status of socio-technical change in Indian automobile industry - A longitudinal study. Global Journal of Flexible Systems Management, 6(3\&4), 25-37.

Genaidy, A.S., Salem, S., Karwowski, W., Paez, O., \& Tuncel, S. (2007). The work compatibility improvement framework: An integrated perspective of the human-at-work system. Ergonomics, $50(1), 3-25$.

Glaser, S. (2006). Viewpoint: The value of the manager in the value chain. Management Decision, 44(3), $442-447$.

Glick, W.H., Huber, G.P., Miller, C.C., Doty, D.H., \& Sutcliffe, K.M. (1990). Studying changes in organizational design and effectiveness: Retrospective event histories and periodic assessments. Organization Science, 1(3), 293-311.

Goold, M., \& Campbell, A. (2002). Do you have a well-designed organization? Harvard Business Review, $80(3), 117-124$.

Griggs, H.E. (2003). Corporatisation of the Not-For-Profit Sector: strategic planning and organisational performance in disability-based organisations. International Journal of Disability, Development \& Education, 50(2), 197.

Haikonen, A., Savolainen, T., \& Jarvinen, P. (2004). Exploring Six Sigma and Cl capability development: preliminary case study findings on management role. Journal of Manufacturing Technology Management, 15(4), 369-378.

Hales, C. (2001). Managing through Organization: The Management process, forms of organization and the work of managers, Second ed., Business Press: Thomson Learning.

Hales, C. (2006). Moving down the line? The shifting boundary between middle and first-line management. Journal of General Management, 32(2), 31-55.

Hamel, G. (2009). Moon Shots for Management: What great challenges must we tackle to reinvent and make it more relevant to a volatile world? Harvard Business Review, 87(2), 91-98. 
Hamlin, R.G. (2002). Towards a generic theory of managerial effectiveness: A meta-level analysis from organisations within the UK public sector - working paper series.

Hamlin, R.G., \& Cooper, D.J. (2004). Identifying the criteria of managerial and leadership effectiveness within the Birmingham women's healthcare NHS trust through HRD professional partnership research. Working Paper Series, (WP010/04), 1-12.

Hamlin, R.G., \& Sawyer, J. (2007). Developing effective leadership behaviours: The value of evidencebased management. Business Leadership Review, 4(4), 1-16.

Hamlin, R.G., \& Serventi, S.A. (2008). Generic behavioural criteria of managerial effectiveness. Journal of European Industrial Training, 32(4), 286-302.

Hasan, I., \& Hunter, W.C. (1996). Management efficiency in minority- and women-owned banks. Economic Perspectives. 20(2), 20-28.

Hodgkinson, M. (2002). A shared strategic vision: dream or reality? The Learning Organization, 9(2), 8995.

Hughes, J.C. \& Rog, E. (2008). Talent management: A strategy for improving employee recruitment, retention and engagement within hospitality organizations. International Journal of Contemporary Hospitality Management, 20(7), 743-757.

Huselid, M. A., Jackson, S.E., \& Schuler, R.S. (1997). Technical and strategic human resource management effectiveness as determinants of firm performance. Academy of Management Journal, 40(1), 171-188.

Jennings, D.F., \& Lumpkin, J.R. (1992). Insights between Environmental Scanning Activities and Porter's Generic Strategies: An Empirical Analysis. Journal of Management, 18(4), 791-803.

Kane-Urrabazo, C. (2006). Management's role in shaping organisational culture. Journal of Nursing Management, 14(3), 188-194.

Kanji, G.K. (2008). Reality check of Six Sigma for Business Excellence. Total Quality Management, 19(6), 575-582.

Kaplan, R., \& Norton, D. (1992). The balanced scorecard - measures that drive performance. Harvard Business Review, 70(1), 71-79.

Kenny, T. (1994). From vision to reality through values. Management Development Review, 7(3), 17-20.

Kerfoot, K. (2007). Staff engagement: It starts with the leader. Nursing Economics, 25(1), 47-48.

Kilgallon, W., \& Lampe, R. (2007). Transformation planning and implementation: An evaluation of processes, experience and future directions. Journal of Medical Marketing, 7(4), 277-286.

Konrad, A.M., Kashlak, R., Yoshioka, I., Waryszak, R., \& Toren, N. (2001). What Do Managers Like to Do? A Five-Country Study. Group \& Organization Management, 26(4), 401-433. 
Kotter, J.P. (2007). Leading Change: Why transformation efforts fail. Harvard Business Review, 85(1), 96-103.

Kraut, A.I., \& Pedigo, P.R. (1989). The role of the manager: What's really important in different management jobs? The Academy of Management Executive, 3(4), 286-293.

Kular, S., Gatenby, M., Rees, C., Soane, E., \& Truss, K. (2008). Employee engagement: A literature review. Working Paper Series, (19), 1-28.

Lau, A.W., \& Pavett, C.M. (1980). The Nature of Managerial Work: A Comparison of Public- and PrivateSector Managers. Group \& Organization Studies, 5(4), 453-466.

Spence Laschinger, H.K., Finegan, J., \& Shamian, J. (2002). The impact of workplace empowerment, organizational trust on staff nurses' work satisfaction and organizational commitment. Advances in Health Care Management, Vol. 36, 59-85.

Lee, K., \& Choi, B. (2006). Six sigma management activities and their influence on corporate competitiveness. Total Quality Management \& Business Excellence, 17(7), 893-911.

Levin, I.M. (2000). Vision revisited: Telling the story of the future. Journal of Applied Behavioral Science, 36(1), 91-107.

Lillrank, P., Lindberg, S., \& Lindberg, P. (2001). Continuous improvement: Exploring alternative organizational designs. Total Quality Management, 12(1), 41-55.

Lloréns-Montes, F.J., \& Molina, L.M. (2006). Six Sigma and management theory: Processes, content and effectiveness. Total Quality Management \& Business Excellence, 17(4), 485-506.

Loch, C.H., Chick, S., \& Huchzermeier, A. (2007). Can European manufacturing companies compete? Industrial competitiveness, employment and growth in Europe. European Management Journal, 25(4), 251-265.

Long, S., \& Spurlock, D.G. (2008). Motivation and stakeholder acceptance in technology-driven change management: Implications for the engineering manager. Engineering Management Journal, 20(2), 30-36.

Lu, Q., \& Botha, B. (2006). Process development: a theoretical framework. International Journal of Production Research. 44(15), 2977-2996.

Luthans, F., Welsh, D., \& Taylor, L. (1988). A descriptive model of managerial effectiveness. Group \& Organization Studies, 13(2), 148-162.

Marr, B. (2004). Measuring and benchmarking intellectual capital. Benchmarking: an International Journal, 11(6), 559-570.

Marr, B., Schiuma, G., \& Neely, A. (2004). Intellectual capital - defining key performance indicators for organizational knowledge assets. Business Process Management Journal, 10(5), 551-569.

Marton, R.L. (2003). The path for top management teams to achieve high-performing council organisations. Australian Journal of Public Administration, 62(4), 50-58.

Matthews, V. (2008). HR's engagement gift list. Personnel Today, 33-33. 
McNabb, R., \& Whitfield, K. (1998). The impact of financial participation and employee involvement on financial performance. Scottish Journal of Political Economy, 45(2), 171-187.

Meade, L.M. \& Rogers, K.J. (2001). Selecting critical business processes: A Case study. Engineering Management Journal, 13(4), 41-46.

Mintzberg, H. (1975). The manager's job: Folklore and Fact. Harvard Business Review, 53(4), 49-61.

Morden, T. (1997). Leadership as vision, Management Decision, 35(9), 668-676.

Morgan, M. (2007). Telling the corporate story: Vision into action. Journal of Business Strategy, 28(1), 26-36-11.

Morgan, A., \& Anthony, S. (2008). Creating a high performance workplace: a review of issues and opportunities. Journal of Corporate Real Estate, 10(1), 27-39.

Mouton, J. (2001). How to Succeed in your Master's and Doctoral Studies: A South African guide and resource book, Pretoria: Van Schaik Publishers.

Nohria, N., \& Berkley, J.D. (1994). Action perspective: The Crux of new Management. California Management Review, 36(4), 70-92.

O'Gorman, C., Bourke, S., \& Murray, J.A. (2005). The Nature of Managerial Work in Small GrowthOrientated Businesses. Small Business Economics, 25(1), 1-16.

O'Connor, G.C., \& DeMartino, R. (2006). Organizing for radical innovation: An exploratory study of the structural aspects of $\mathrm{RI}$ management systems in large established firms. Journal of Product Innovation Management, 23(6), 475-497.

Page, C., Wilson, M., \& Meyer, D. (1999). A three domain, two dimension model of managerial effectiveness. Paper presented at the Academy of Business and Administrative Sciences conference, Barcelona, Spain.

Papadimitriou, D., \& Taylor, P. (2000). Organisational Effectiveness of Hellenic National Sports Organisations: A multiple constituency approach. Sport Management Review, 3, 23-46.

Paton, N. (2007). Poor middle managers paralyzing UK economy. Retrieved 25 November 2008, from http://www.management-issues.com/2007/2/7/research/poor-middle-managers-paralysing-ukeconomy.asp

Patterson, M.G., West, M.A., Lawthom, R., \& Nickell, S. (1997). Issues in People Management: Impact of People Management Practices on Business Performance. Institute of Personnel and Development, London: Cromwell Press.

Pearson, C.A.L., \& Chatterjee, S.R. (2003). Managerial work roles in Asia: an empirical study of Mintzberg's role formulation in four Asian countries. Journal of Management Development, 22(8), 694-707.

Peppard, J. (2000). Customer relationship management in financial services. European Management Journal, 18(3), 312-327. 
Pfeffer, J. (2005). Producing sustainable competitive advantage through the effective management of people. Academy of Management Executive, 19(4), 95-106.

Porter, M.E. (1985). Competitive Advantage, New York: Free Press.

Reidenbach, R.E., \& McClung, G.W. (1999). Managing stakeholder loyalty: When satisfaction is just not enough. Marketing Health Services, 19(1), 21-29.

Salaman, G., \& Asch, D. (2002). Improving organisational performance. European Business Journal, 14(4), 186.

Schaufeli, W.B., \& Bakker, A.B. (2010). Defining and measuring work engagement: Bringing clarity to the concept. In A.B. Bakker \& M.P. Leiter (eds.) Work Engagement: A Handbook of Essential Theory and Research (pp. 10-24). New York: Psychology Press.

Schermerhorn, J.R.J. (2004). Core concepts of Management. New York: John Wiley \& sons.

Sohal, A.S., Schroder, R., Uliana, E.O., \& Maguire, W. (2001). Adoption of AMT by South African manufacturers. Integrated Manufacturing Systems, 12(1), 15-34.

Simpson, M.R. (2008). Engagement at work: A review of the literature. International Journal of Nursing Studies, 46(7), 1012-1024.

Slaughter, R.A. (1999). A New Framework for environmental scanning. Foresight, 1(5): 441-451.

Subramanian, R., Fernandes, F., \& Harper, E. (1993). Environmental scanning in US companies: Their nature and their relationship to performance. Management International Review, 33(3), 271-286.

Tan, K., Kannan, V.R., Handfield, R.B., \& Ghosh, S. (1999). Supply chain management: an empirical study of its impact on performance. International Journal of Operations \& Production Management, 19(10), 1034-1052.

Taylor, F. (1911). Principles of Scientific Management. New York and London, Harper Brothers.

Towers Perrin Global Workforce Study - Global Report (2007). Closing the engagement gap: A road map for driving superior business performance. www.towersperrin.com.

Van der Velde, M.E.G., Jansen, P.G.W. \& Vinkenburg, C.J. (1999). Managerial Activities among Top and Middle Managers: Self Versus Other Perceptions. Journal of Applied Management Studies, 8(2), 161-64.

Verma, D.P.S., \& Kajendra, K. (2004). Influence of customer-orientation on organisational performance: A study of large manufacturing companies in Sri Lanka. Decision (0304-0941), 31(1), 125-144.

Veldsman, T.H. (n.d.). People management in the new order: In pursuit of the leading practices of world class people management. Unpublished manuscript.

Veldsman, T.H., \& Roodt. G. (2002). Organisational success within the South African business Context: A benchmarking study. Johannesburg: University of Johannesburg.

Wailand, C.B. (2002). A new David preparing for a new Goliath: A Question of corporate competence. World Futures, 58(5-6), 433-440. 
Weinstein, A., \& Barrett, H. (2007). Value Creation in the Business Curriculum: A Tale of Two Courses. Journal of Education for Business, 82(6), 329-336.

Wigham, R. (2003). Staff commitment wanes four years in a row. Personnel Today, 4-4.

Wing, L.S. (2005). Leadership in high-performance teams: A model for superior team performance. Team Performance Management, 11(1/2), 4-11.

Wiley, W.W., Brooks, S.M., \& Hause, E.L. (2000). The Impact of Corporate Downsizing on Employee Fulfilment and Organizational Capability. In K.P. De Meuse \& M.L. Marks (editors), Resizing the Organization: Managing Layoffs, Divestitures, and Closings. Maximizing Gain While Minimizing Pain (p. 108). USA: San Francisco. Jossey-Bass.

Yarrow, D., Robson, A., \& Owen, J. (2004). Organizational Excellence: Do your Stakeholders Agree? Total Quality Management, 15(5-6), 869-878.

Yasai-Ardekani, M., \& Nystrom, P.C. (1996). Designs for Environmental Scanning Systems Tests of a Contingency Theory. Management Science, 42(2), 187-204.

Zakhem, A. (2007). Stakeholder Management Capability: A Discourse-Theoretical Approach. Journal of Business Ethics, 79(4), 395-405. 